\title{
Ativismo Judicial: função jurisdicional como criação de direitos
}

\author{
DOI: 10.47224/rm.v5i10.92
}

Geilson Nunes

Fabrício da Cruz Pereira

e-mail: capgeilson41@gmail.com

\begin{abstract}
Resumo
A presente pesquisa teve por objetivo esclarecer o Ativismo Judicial e seus aspectos doutrinários com fundamentos na Constituição Federal de 1988, por meio de uma atuação expansiva do judiciário. Para atingir os objetivos propostos, percorreu-se o caminho histórico do ativismo judicial e sua conceituação. Em segundo passo, tratou da tripartição dos poderes como forma de divisão das funções do estado, apontando seus pontos positivos e negativos e as consequências que representa para a democracia brasileira. Na sequência, analisou os conflitos de normas pelo poder judiciário frente ao art. 5 da Constituição Federal e a Segurança Jurídica transmitida para toda a sociedade. Para tanto o método de pesquisa utilizado foi o dedutivo através do diálogo das diversas fontes que tratam do tema, a partir de argumentos gerais para argumentos particulares, de forma a almejar melhores resultados para a problemática em tela e uma metodologia a partir de uma pesquisa essencialmente bibliográfica, calçada na norma constitucional, na lei, na doutrina e na jurisprudência que tratam o tema
\end{abstract}

Palavras-chave: Ativismo Judicial. Interpretação Constitucional. Segurança Jurídica

\begin{abstract}
This research aimed to clarify Judicial Activism and its doctrinal aspects based on the Federal Constitution of 1988 , through an expansive performance of the judiciary. To achieve the proposed objectives, the historical path of judicial activism and its conceptualization was followed. In the second step, it deal twenty the tripartite on of the powers as a way of dividing the functions of the state, pointing out its positive and negative points and the consequences it represents for Brazilian democracy. In the sequence it analyzed the conflicts of norms by the judiciary before the art. 5 of the Federal Constitution and the Legal Security transmitted to the whole society. Therefore, the research method used was the deductive through the dialogue of the various sources that deal with the theme, from general arguments to particular arguments, in order to achieve better results for the problem at hand and a methodology based on a research essentially bibliographic, based on the constitutional norm, the law, the doctrine and the jurisprudence that deal with the subject.
\end{abstract}

Keywords: $\quad$ Judicail Activism. Constitucional Interpretation. Legal Security.

\section{INTRODUÇÃO}

A pesquisa em tela tratará do Ativismo Judicial, tendo em vista que a atuação expansiva do Poder Judiciário em que este ultrapassa o limite da lei e dos poderes constituídos, executivo e Legislativo ferindo a independência existente entre eles gerando insegurança jurídica. Assim, buscaremos onde surgiram os movimentos ativistas, conceituação, aplicação da Suprema Corte frente aos direitos fundamentais previstos na Constituição Federal de 1988.
Neste sentido, analisará a forma que a constituição institui os seus poderes na visão do Poder Originário com a tripartição dos poderes, em busca de distribuir as funções típicas de cada um para atender as demandas sociais, como forma de regular a ação do homem na vida em sociedade.

Adiante, tratarão dos conflitos de normas existentes no ordenamento jurídico pátrio, as divergências entre normas internas e a constituição e normas externas e a constituição, como essas normas originadas do campo internacional em que o Brasil é signatário e se pode mudar o sentido do texto constitucional, o que 
nos leva ao ativismo judicial desenvolvido pelo sistema judiciário que ultrapassa os limitem dos três poderes, gerando insegurança jurídica por parte dos doutrinadores frente ao entendimento da norma vigente.

A pesquisa objetiva-se a buscar respostas para as perguntas apostas, sob o enfoque crítico e analítico do ativismo judicial, de forma a reconhecer se tal prática é lesiva ou não ao Estado Democrático de Direito e se pode, de alguma forma, contribuir para a efetivação de direitos.

A importância deste estudo encontra-se na busca da atualidade do tema e na polêmica que o envolve em nome de uma atuação legítima do Poder Judiciário, em especial do Supremo Tribunal Federal, na forma de preservação dos preceitos do Estado Democrático de Direito, lembrando que as decisões em âmbito de jurisdição constitucional têm um impacto em toda a sociedade e no próprio direito brasileiro.

Será utilizada na realização da pesquisa o método de abordagem dedutivo, considerando que o estudo parte da compreensão das regras gerais que norteiam o tema, para as premissas particularidades que se apoiarão na teoria de base proposta. A técnica de pesquisa escolhida será a de análise de documentação indireta, pesquisa bibliográfica, utilizando as fontes sobre a temática a ser estudada.

Por fim, entende-se que não pode haver este fenômeno, pois irá criar direitos, desestabilizando a democrática por via da justiça, quando deveria gerar segurança jurídica ao interpretar de forma imparcial com amparo legal da norma.

\section{CONCEITO E SURGIMENTO DO ATIVISMO JUDICIAL NO BRASIL}

A expressão judicial activism surgiu pela primeira vez através do jornalista norte-americano, Arthur Schlesinger Jr., num artigo escrito na revista Fortune em janeiro de 1947, intitulado The Supreme Court: 19478. Assim tronou-se público um grande clássico nos estudos da jurisdição constitucional.

Este jornalista tinha por escrever a respeito dos Presidentes da República, principais atos dos líderes políticos de perfil liberal, tais como Franklin D. Roosevelt, John F. Kennedy, e Robert F. Kennedy. Inclusive no governo do Presidente John Kennedy prestou assessoria na missão de historiografar a Suprema Corte.

Naquele momento havia dentro da corte americana uma espécie de rebeldia entre os juízes que, diante do cenário econômico dos Estados Unidos declarou inconstitucionais algumas leis feitas na tentativa de retomar a economia, desagradando o Presidente americano que chegou a fazer proposta em aumentar o número de juízes da Corte.

Para o jornalista havia duas correntes dentro da Corte, uma praticava o ativismo judicial tido como instrumento para alcançar a justiça social, e a outra optava pela autocontenção permitindo que o Poder Legislativo elaborasse políticas voltadas para essas questões por meio das maiorias exigidas no processo democrático.

Em 1988 com a promulgação da Constituição Federal da República, iniciou-se um período de redemocratização no país introduzindo no texto constitucional um rol de direitos sociais para os cidadãos brasileiros. Trouxe também a possibilidade de revisão judicial dos atos dos demais Poderes, o Supremo Tribunal Federal assumiu essa função de zelar e fazer cumprir a Constituição, a partir desse momento surgem os primeiros debates sobre ativismo judicial no país.

No Brasil, devido à intensa judicialização das políticas públicas e relações sociais devido à insuficiente atuação do poder Legislativo e Executivo, que devido à crescente necessidade da população, tem-se recorrido ao poder Judiciário em busca da pretensão dos direitos sociais, surgindo práticas judiciais lesivas ao Estado Democrático de Direito, por violar o princípio da separação de poderes, sendo Supremo Tribunal Federal guardião da Constituição.

Streck (2016, p. 99-100), ensina que o ativismo sempre será ruim para a democracia, devido aos comportamentos e visões pessoais dos juízes e tribunais e, para que haja preservação dos direitos fundamentais estes só deveriam ser chamados quando houvesse violação da Constituição por parte de um dos poderes constituídos. Em relação específica da judicialização da política a vontade do julgador se faz no lugar dos debates.

Para o autor supracitado, o Ativismo é uma consequência da judicialização e que esta é um fenômeno típico das sociedades contemporâneas, devido a sua complexidade e pluralidade. Às vezes a complexidade da sociedade é muito rápida devido aos movimentos por ela imposta, em que os poderes políticos não conseguem acompanhar.

Kelsen (2000, p. 393), dentre vários conceitos possíveis, o ativismo é fruto da interpretação como ato de vontade, tendo com fatores influenciadores os políticos e morais. A história do direito através de seus filósofos desenvolveu teorias como meio de 
controle racional interpretativo, que remete ao campo da subjetividade hermenêutica como nos ensina.

Na medida em que, na aplicação da lei, para além da necessária fixação da moldura dentro da qual se tem de manter o ato a pôr, possa ainda ter uma atividade cognoscitiva do órgão aplicador do Direito, não se tratará de um conhecimento do Direito Positivo, mas de outras normas que aqui no processo de criação jurídica, podem ter sua incidência: normas de Moral, normas de Justiça, juízos de valor sociais que costumamos designar por expressões correntes como bem comuns, interesse do Estado, progresso, etc.

Desde a promulgação da Constituição de 1988, ocorre uma expansão da jurisdição constitucional no Brasil, para Barroso (2009, p. 285) uma das causas determinantes foi à ampliação do direito de propositura no controle concentrado, enquanto mero instrumento de governo passou a admitir que minorias políticas e segmentos sociais menos representativos pudessem propor tal controle. 0 surgimento do Ativismo Judicial na ótica de Barroso é uma atitude, advinda de uma escolha do modo adotado e específico interpretativo da Constituição, fazendo com que seu alcance e sentido sejam expandidos. Isto ocorre quando o Poder Judiciário se faz pronunciar sobre assuntos no campo de atuação do Legislativo e do Executivo.

Para Appio (2008, p. 194) esse ativismo judicial é uma característica do judiciário contemporâneo que surgiu devido às ações desempenhadas fora das suas funções. Há doutrinadores que considera uma crítica seguindo essa corrente. Essa postura hermenêutica em que o julgador age como comparticipe da criação da norma, abre espaços de discricionariedade, estes servem de porta de entrada de elementos políticos e morais, onde o intérprete passa a decidir conforme sua vontade.

Também tem quem entende que no Brasil, esse ativismo está ligado a um objetivo claro e concreto dos juízes na garantia dos direitos sociais diante da falta de recursos financeiros. Isto se dá devido à falha do poder Executivo na garantia dos direitos fundamentais e sociais previstos na Constituição Federal de 1988, bem como o poder Legislativo não disciplina por meio de leis qual mecanismo será usado para atender a sociedade nas suas necessidades básicas constitucionais.

De acordo com Streck (2011, p. 190):

Em síntese, é a situação hermenêutica instaurada a partir do segundo pós- guerra que proporciona o fortalecimento da jurisdição (constitucional), não somente pelo caráter hermenêutico que assume o direito, em uma fase pós-positivista e de superação do paradigma da filosofia da consciência, mas também pela força normativa dos textos constitucionais e pela equação que se forma a partir da inércia na execução de políticas públicas e na deficiente regulamentação legislativa de direitos previstos nas Constituições. É nisto que reside o que se pode denominar de deslocamento do polo de tensão dos demais poderes em direção ao Judiciário.

Tassinari $(2013$, p. 33) ensina que em decorrência do poder de revisar ser discricionário, gera uma maior interferência do judiciário diante da capacidade de gerenciamento processual do julgador, impulsionados por fatores políticos e morais.

A questão é saber diferenciar quando está ocorrendo o ativismo e compreender dentro da hermenêutica a que é interpretação da lei daquilo que aparenta ser uma invasão a esfera de competência legislativa. Isso retrata as questões políticas, que não deveriam ser levadas aos tribunais para não serem analisadas por convicções políticas de cada magistrado.

Há que se diferenciar Judicialização de Ativismo Judicial, enquanto diante a nova constituição consagrando novos direitos difusos estes quando não são colocados em prática ou não são aplicados e diante da necessidade social ocorre a Judicialização, pois a través do poder judiciário o cidadão busca a satisfação de um direito constitucional inundando o Poder Judiciário de demandas oriundas da omissão do Executivo e Legislativo.

O Ministro do STF, professor de direito constitucional Luís Roberto Barroso considera a Judicialização e Ativismo Judicial como primos, ou seja, são da mesma família. A primeira dentro do contexto brasileiro é um fato, decorrente do modelo constitucional que se adotou. Se uma norma constitucional permite dentro de uma pretensão subjetiva ou objetiva, cabe ao juiz decidir a matéria. Já o ativismo judicial é uma atitude, modo específico de escolha para interpretar a Constituição, causando expansão no seu alcance e seu sentido. Isso ocorre em relação ao Poder Legislativo, em que as demandas sociais não são atendidas efetivamente.

O ativismo judicial está liga do a uma participação mais ampla e intensa do Judiciário na concretização dos valores e fins constitucionais, isto invade os outros dois Poderes. Esta atitude ocorre na aplicação 
direta da Constituição em situações não previstas pelo legislador ordinário no controle de inconstitucionalidade de atos normativos e omissão do Poder Público em aplicação das políticas públicas.

Dias e Oliveira (2017, p. 151) esclarecem que a exposição de votos e televisionamento das sessões, são impertinentes e desnecessárias mostrando a controvérsia dentro da mais alta corte do país ilustrando o tema debatido, bem como é quase impossível que não sejam extraídos dos votos as questões e viés político de cada ministro.

Por outro lado, diante os casos em que o juiz tem que analisar quando é demandado e coloca sua vontade em decidir e aplica sua vontade na decisão estaremos diante do ativismo judicial, ou seja, o que impera é a vontade do julgador de transformar a sociedade conforme seu desejo pessoal.

Diante da ótica dos juristas norte-americanos, a intensificação da atividade jurisdicional, é defendida um necessário ativismo judicial para concretizar direitos. Criou-se um imaginário jurídico a dependerse das decisões judiciais sobre questões mais relevantes da sociedade, tendo uma função com viés de solução para as demandas da sociedade.

Uma corte como o Supremo Tribunal Federal desempenha em um dos seus papéis funcionais o do contra-majoritário na declaração de inconstitucionalidade de uma lei ou ao anular um ato do Presidente da República, sem que tenha recebido nenhum voto, sobrepondo a vontade popular investida em seus representantes eleitos pelo voto fazendo prevalecer à decisão judicial em detrimento do legislativo ou executivo.

Ao contrário do ativismo, ensina Barroso (2018, p. 449) que o oposto é a autocontenção judicial, essa conduta é quando o judiciário reduz a sua interferência nas ações dos outros poderes. A principal diferença é que o ativismo busca legitimar o exercício de seu poder na interpretação do texto constitucional em regras específicas de condutas a partir de enunciados vagos, por sua veza autocontenção busca priorizar os espaços dos poderes políticos em relação as suas ações e omissões.

Dias e Oliveira (2019, p. 159-160) ensinam ainda que a interpretação constitucional não deve criar direitos, esses devem ser extraídos literalmente da lei, ou seja, ater-se a vontade do legislador na disposição normativa para que essa interpretação não extrapole a função judicial e entre na legislativa. A fundamentação da decisão judicial deve observar a razoabilidade da motivação do texto constitucional, evitando inovação legislativa trazidas do imaginário dos julgadores.

Assim, os juízes devem ter extremos cuidados e zelo diante dos casos concretos para na aplicação hermenêutica da lei, não ter uma interpretação ativista invadindo a esfera legislativa se tornando questões políticas, essas questões de natureza política seria bom que não fossem submetidas a corte para que os magistrados também não decidissem com suas convicções políticas. Um novo cenário político após a promulgação da constituição de 1988 trouxe um desenvolvimento e reconhecimento da independência judicial como valor essencial do Estado de direito.

Por fim, o que se busca na interpretação expansiva é diverso, o que se destaca é o fim político, este não deveria existir, e deverá imperar na análise da aplicação do direito no fato em si. Antonin Scalia (2012, n.p.) adverte que os juízes "propositivistas" extraem do texto o sentido que eles buscam a partir de um propósito que não o sentido do texto, sobrepondo a vontade do legislador, inovando o ordenamento jurídico usurpando a função legislativa, o juiz deve pronunciar as palavras da lei e não o que vai além da norma escrita tornando aplicação do imaginário do que o intérprete acha justo e conveniente.

O Poder Judiciário deve ater-se como guardião da constituição em sem interferência externa da ordem política ou legislativa, e se alguém a ferir, deve intervir legalmente para fazer com que todos a possam cumprirem fielmente. $O$ não cumprimento das obrigações por parte do Poder Legislativo e Executivo não devem ser ignorados pelo Poder Judiciário, não está dentro da sua função dirimir problemas além daquilo que a Constituição Ihe permite resolver. Uma das causas para uma atuação expansiva do judiciário são os remédios constitucionais usados para resolver questões dos outros poderes.

\section{TRIPARTIÇÃO DOS PODERESNACONSTITUIÇÃO FEDERAL DE 1988}

Desde a idade antiga os filósofos já falavam da separação dos poderes de um Estado e, com o passar do tempo, já na Idade Moderna esse tema ganhou algumas formas de se entender o que seria melhor para um sistema jurídico.

Para Locke, seriam quatro funções e dois órgãos de Poder do Estado: o parlamento função legislativa e a executiva para o rei com acúmulo da federativa 
(segurança, guerra, paz) ligas e alianças e a outra o poder de fazer o bem público sem se subordinar a regras.

Montesquieu (2000, p. 167-168) define a estrutura tripartite do poder do Estado da seguinte forma:

Existem em cada Estado três tipos de poder: o poder legislativo, o poder executivo das coisas que dependem do direito das gentes e o poder executivo daquelas que dependem do direito civil. Com o primeiro, o príncipe ou magistrado cria leis por um tempo ou para sempre e corrige e anula aquelas que foram feitas. Com o segundo, ele faz a paz ou a guerra, envia ou recebe embaixadas, instaura a segurança, previne invasões. Com o terceiro, ele castiga os crimes, ou julga as querelas entre os particulares. Chamaremos a este último poder de julgar e ao outro simplesmente poder executivo do Estado.

Assim criou a tese clássica da conhecida tripartição de Poderes: Legislativo, Executivo e Judiciário. Em 1988 o poder constituinte através da Constituição da República Federal em seu art. 2o adotou a essa tese dos poderes da União, independentes e harmônicos entre si, o Legislativo, o Executivo e o Judiciário. Como é uma constituição cidadã e principiológica, impera o princípio da separação dos poderes, ou seja, um poder não pode invadir a jurisdição do outro para que não se quebre o equilíbrio existente entre eles.

$\mathrm{Na}$ visão de Barroso (2018, p. 457), o principal elemento entre a política e o direito é a constituição, é o que transforma o poder constituinte originário advindo da soberania do povo em seu estado quase puro em poder constituído. O poder do Estado vem dessa manifestação de vontade do povo pela constituição, atribuindo poderes as instituições distribuindo-lhes competências diversas. Em que dois deles são políticos, o Poder Legislativo na criação do direto positivo, o Poder Executivo com função de chefe de estado e governo e por fim com uma função mais técnica o Poder Judiciário.

Existe uma forma para controlar os poderes dentro de um sistema jurídico, como mecanismo de evitar normas tirânicas e governos absolutistas Montesquieu criou o Sistema de freios e contrapesos, onde só o poder pode controlar poder. Sendo assim, os poderes são autônomos com funções definidas e controlado por outro poder. Esse Sistema faz com que um Poder do Estado pode conter abusos do outro e o contrapeso é que todo o poder tem as suas funções distintas com harmonia e independência entre si.
Ensina Barbosa e Saracho (2019, p. 1630):

\begin{abstract}
O Sistema de Freios e Contrapesos consiste no controle do poder pelo próprio poder, sendo que cada Poder teria autonomia para exercer sua função, mas seria controlado pelos outros poderes. Isso serviria para evitar que houvesse abusos no exercício do poder por qualquer dos Poderes (Executivo Legislativo e Judiciário). Desta forma, embora cada poder seja independente e autônomo, deve trabalhar em harmonia com os demais Poderes.
\end{abstract}

Continua os autores supracitados, considerando o preâmbulo da Constituição Federal brasileira de 1988 que a Assembleia Nacional Constituinte, criou um Estado Democrático, para assegurar o exercício dos direitos sociais e individuais, a liberdade, a segurança, bem como tantos outros buscando uma harmonia social interna e externa, com a solução pacífica das controvérsias.

Diante os princípios dispostos na Carta Constitucional brasileira de 1988 temos que os poderes (Legislativo, Executivo e Judiciário) estão estruturados na independência e harmonia entre si. A separação dos poderes é uma garantia constitucional para estabelecer funções diferenciadas, no exercício legal de cada um. A separação dos poderes no Brasil garante um o Estado Constitucional Democrático de Direito, os três poderes (Legislativo, Executivo e Judiciário) devem buscar aplicar um propósito social.

Esses poderes têm suas funções típicas bem definidas. Ao Poder Legislativo cabe legislar e fiscalizar, sua composição é bicameral, sendo a Câmara dos deputados e Senado Federal é exercido pelo Congresso Nacional, diferenciando dos demais estados da federação, distritais e municipais, que são compostos pelo unicameralismo (CF, arts. 27,29 e 32). O legislador constituinte ao escolher o bicameralismo para a forma federativa de Estado, colocou o Senado Federal de forma paritária entre todos os Estados membros e do Distrito Federal equilibrando-os.

O poder legislativo tem por função básica fazer leis através do Congresso Nacional (Senado Federal e Câmara dos Deputados Federal) representando o povo na fiscalização do poder Executivo através do tribunal de contas e autoridades públicas através das Comissões Parlamentares de Inquéritos. O Senado Federal tem a incumbência de julgar o presidente e o vice-presidente da República e os ministros de Estado 
no caso de crimes de responsabilidade, após a autorização da Câmara dos Deputados para instaurar o processo.

A Câmara dos Deputados é a casa do povo representada pelos seus eleitos através do sistema proporcional, composta por 513 deputados eleitos para um mandato de quatro anos, essas cadeiras são divididas entre os 26 estados e Distrito Federal para cumprirem a função de representação de acordo o estado de origem. Em regra, é onde começam a tramitar os projetos de lei, chamada de casa iniciadora. Também exercessem a função de legislar onde elaboram, revisam e aprovam leis de interesses dos mais variados temas, para isso, os deputados devem conhecer da necessidade da população e buscar uma solução legislativa em benefício de um todo na fiscalização da aplicação dos recursos públicos.

A Constituição Federal de 1988 em seu art. 51 determina competência privativa para autorizar a instauração de processo de impeachment contra o Presidente, Vice-Presidente da República bem como dos Ministros de Estado.

O Senado Federal compõe-se de representantes dos Estados e do Distrito Federal, eleitos pelo sistema majoritário que é através do maior número de votos. Cada Estado e o Distrito Federal terão três senadores, com mandato de oito anos. O Senado cuida dos interesses dos estados federados e privativamente julga o Presidente, Vice-Presidente da República bem como dos Ministros de Estado nos crimes de responsabilidade.

Cada poder exerce uma função típica dentro do Estado, sendo assim o Executivo representado pelo próprio Governo na forma de uma república presidencialista constituído pelo Presidente da República e assessorado pelos Ministros de Estado, tem a função administrativa de gestão e de cumprir as leis. Este tem uma função atípica de legislar através das Mediadas Provisórias em caso urgência e necessidade extraordinária.

O Poder Executivo tem por função típica aplicar a lei. No Brasil, adotou-se um Executivo monocrático com o sistema presidencialista em que as funções de Chefia do Estado e de Governo são exercidas pelo mesmo agente político. O Chefe de Estado é quem representa a República nas relações internas e externas atuando em relações com Estados estrangeiros, celebração de tratados, dentre outros.

Incumbe ao Presidente gerenciar a administração pública disciplinando as atividades administrativas, propor projetos de lei, editar de medidas provisórias, fazer o planejamento e controle orçamentário, criar cargos dentro da máquina estatal, nomear os cargos de confiança, ou seja, administrar eficazmente a administração pública de forma a atender os anseios sociais.

O Poder Judiciário é um dos três poderes dentro da Constituição Federal, também é autônomo e independente, como pressuposto para um Estado de Direito, tem por função administrar a Justiça, e verdadeiro guardião da Constituição na preservação dos princípios da legalidade e igualdade, organização política, diante das necessidades jurídicas na solução de conflitos, para isso a Constituição Federal em seu art. 92 descreve os órgãos que compõe o Poder Judiciário e entre eles no inciso I está o Supremo Tribunal Federal.

Após uma análise do cenário atual e diante o que já se passou na história mundial em busca do modelo ideal de constitucionalismo, chegou- se ao seguinte entendimento na visão de Barroso (2019, p. 482) "Democracia significa soberania popular, governo do povo, vontade da maioria. Constitucionalismo por sua vez, traduz a ideia de poder limitado e respeito aos direitos fundamentais, abrigados, como regra geral, em uma constituição escrita". Ao Poder Judiciário coube a de proteção a constituição para garantir um Estado de Direito e dos Direitos Fundamentais, onde a cúpula é o Supremo Tribunal Federal.

Dessa forma, a função típica do Poder Judiciário é jurisdicional, ou seja, julgar, aplicando a lei a um caso concreto, que lhe é posto, resultante de um conflito de interesses, exercendo o poder de aplicar a lei nos casos em que são demandados na apreciação judicial e o Supremo Tribunal Federal como guardião da Constituição Federal é o responsável pela interpretação de seus dispositivos. O juiz deve aplicar a lei nas demandas judiciais de forma imparcial e motivando o livre convencimento, ao contrário estaria exercendo um papel representativo na decisão de temas oriunda das necessidades sociais e políticos diante da omissão do congresso nacional.

A função jurisdicional está materialmente limitada aos mandamentos do poder legiferante, para alguns essa função poderia estar separada das demais, o que não justifica invasão ao Poder Legislativo, ou seja, deveria ser a boca que pronuncia a lei e não a que a cria.

Neste sentido, a nossa Constituição federal de 1988 é tratada como uma constituição dirigente, o seu sentido ultrapassa a manutenção do status quo bem como a organização estatal. Está dentro da sua vontade à questão de transformação social, 
estabelecer na realização de políticas públicas pelo Estado na busca de redução e erradicação da pobreza no Brasil contemporâneo.

Nesta ótica, o que se percebe é o aumento das funções institucionais do Poder Judiciário, com a criação de mecanismo como o controle de constitucionalidade de competência exclusiva do Supremo Tribunal Federal, que no exercício do seu dever quando dos julgamentos das ações direta de inconstitucionalidade, declaratória de constitucionalidade, arguição de descumprimento de preceito fundamental e mandado de injunção, ao prolatar interpretação delicada da constituição.

\section{CONFLITOS DE NORMAS NA ATUAÇÃO DO PODER JUDICIÁRIO NO ART 5 DA CONSTITUIÇÃO FEDERAL DE 1988 E A SEGURANÇA JURÍDICA}

O Poder Judiciário composto pelos seus órgãos jurisdicionais, em que o Supremo Tribunal Federal tem como função precípua a de guardião da Constituição no controle abstrato da norma, última instância para recurso deveria agir com firmeza então deixar influência externa contaminar as suas decisões quer seja no campo político quer seja no social.

Houve uma ascensão do poder judiciário devido a reconstitucionalização do país, os juízes e tribunais deixaram de exercer um papel técnico e passaram ao campo político em razão da demanda social na justiça brasileira. Isso fez com que esses atores ocupassem uma posição centralizada na vida das pessoas.

O art. 5o, inciso LXVII que trata da prisão do depositário infiel mediante ao Pacto de São José da Costa Rica Decreto № 678, de 6 de novembro de 1992que instituiu a Convenção Americana sobre Direitos Humanos do qual o Brasil é signatário em seu art. 70 diz que "ninguém deve ser detido pro dívida", o Código Civil de 2002 em seu artigo 652 diz que "o depositário que não o fazer quando exigido será compelido a fazer mediante prisão civil". Estamos diante de um conflito de normas, temos dispositivo constitucional Dos Direitos e Garantias Fundamentais alterado por uma norma internacional positivado por uma Súmula Vinculante no 25 do STF. Em relação ao disposto no Código Civil não há dúvida da legalidade de não se aplicar o art. 652 por ser uma norma infraconstitucional que foi superada por outra com status de supra legal.

Para a internalização de um tratado dentro do nosso ordenamento jurídico o processo é dificultoso devido a nossa constituição ser rígida em relação aos direitos fundamentais. $\mathrm{O}$ procedimento inicia-se na câmara dos deputados com a leitura da mensagem do Presidencial, posteriormente encaminhada para a Comissão de Relações Exteriores e de Defesa Nacional.

É designado um relator que após análise propõe um projeto de decreto legislativo sobre o texto do tratado internacional, com aprovação passa para a Comissão de Constituição, Justiça e Redação para novo exame. Aprovado, o projeto é submetido à discussão e votação em dois turnos no Plenário da Câmara dos Deputados, com quórum qualificado, ou seja, três quintos.

Após votação em dois turnos e com quórum qualificado, e com a sua aprovação, encaminha-se ao Presidente do Senado, como Presidente do Congresso Nacional, para promulgação e publicação do Decreto Legislativo. O Tratado Internacional de direitos humanos é aceito no direito pátrio como uma norma constitucional, pois equivale a uma Emenda Constitucional.

Em relação aos conflitos das normas de direito internacional e interno há que considerar qual será a prevalência entre elas, visto que as regras de solução podem nos confundir com os próprios princípios. Se a decisão que prevalecer for internacional, esta se consagrará superior a interna e no contrário a jurisprudência diz que haverá diferentes soluções.

Para Sampaio (2018, p.225), haverá autoridade relativa do tratado e de outras fontes na ordem interna quando que o juiz não violar o tratado, que reconhecer a superioridade do tratado sobre a lei mais recente em data e reconhece essa superioridade com ligação de um controle jurisdicional da constitucionalidade da lei.

Ensina Kinchescki (2006, p. 82), diante da aceitação e internalização de tratados internacionais, estes tem como fundamento da sua obrigatoriedade a norma pacta sunt servanda, esse entendimento está de acordo com o renomado autor Hans Kelsen (1998, p.81) "segundo a qual os Estados ficam vinculados aos tratados por eles celebrados, qualquer que seja o conteúdo que eles deem às normas praticamente criadas."

Para Ramos (2015, p. 281) a Constituição tem característica rígida, supremacia formal, bem como tem prevalência hierárquicas entre os demais atos normativos do nosso ordenamento. A aplicação em âmbito interno deve fundar-se na Lei Fundamental e não em normas infraconstitucionais ou pertencentes à ordem internacional. 
O STF analisou novamente a prisão por dívida conforme Recurso Extraordinário 466.343-1. Interpretação do art. 5으, inc. LXVII e $\S \S 1$, 2ㅇ e 3으, da $C F$, à luz do art. 7오 $\S 7$, da Convenção Americana de Direitos Humanos (Pacto de San José da Costa Rica). Julgamento conjunto do RE no 349.703 e dos HCs no 87.585 e no 92.566 onde a jurisprudência a respeito do tema foi dívida dentro da corte, embora que a tese que prevaleceu foi a do Ministro Gilmar Mendes. É como vota o ministro:

Nesse sentido, é possível concluir que, diante da supremacia da Constituição sobre os atos normativos internacionais, a previsão constitucional da prisão civil do depositário infiel (art. 50, inciso LXVII) não foi revogada pelo ato de adesão do Brasil ao Pacto Internacional dos Direitos Civis e Políticos (art. 11) e à Convenção Americana sobre Direitos Humanos - Pacto de San José da Costa Rica (art. 70, 7), mas deixou de ter aplicabilidade diante do efeito paralisante desses tratados em relação à legislação infraconstitucional que disciplina a matéria, incluídos o art. 1287 do Código Civil de 1916 e o Decreto-Lei $n^{\circ} 911$, de 1 으 de outubro de 1969.

Como se vê como o Brasil é signatário do Pacto de San Jose da Costa Rica, o tribunal entendeu o status supralegal, mas infraconstitucional dos tratados e convenções internacionais sobre direitos humanos. $O$ STF deixou de aplicar o dispositivo constitucional da prisão do depositário infiel em virtude de um tratado internacional sob a ótica de que o tratado não mudou a constituição tão somente paralisou sua eficácia, estamos diante de uma total antinomia visto que, o artigo 50 da $\mathrm{CF} / 88$ é cláusula Pétrea não pode ser mudada nem mesmo por emenda constitucional quem dirá por um tratado internacional.

A Emenda Constitucional no 45 de 2004, deu ao Supremo Tribunal Federal o poder de usar o instituto da súmula vinculante, sendo assim a "súmula que, a partir de sua publicação na imprensa oficial, terá efeito vinculante em relação aos demais órgãos do Poder Judiciário e à administração pública direta e indireta, nas esferas federal, estadual e municipal", é o que diz o artigo 103-A da Constituição da República Federativa do Brasil.

Para Campos (2014, p. 237) a aplicação dessas súmulas requer interpretações como qualquer outra norma em abstrato ou no caso concreto. Para tanto, ao STF lhe é dado poder político-normativo, característica legiferante, em consequência vincula Estado, administração pública, as demais instâncias judiciais e a própria sociedade, a independência e harmonia entre o poder Judiciário e Legislativo.

Ilustra Campos (2014, p. 250) dois importantes e controvertidos casos em que o STF sem sombra de dúvida invadiu a esfera legislativa e fez criar direitos, a consideração da união homoafetiva como entidade familiar e a do aborto de fetos anencéfalos (má formação do cérebro durante a formação embrionária). No primeiro caso diante da omissão legislativa equiparou na esfera jurídica a união estável homoafetiva (pessoas do mesmo sexo) com a união estável heteroafetiva (pessoas de sexo diferente). No segundo caso incluiu uma excludente de ilicitude para a prática do aborto de fetos anencéfalos.

A Corte concluiu o julgamento das Ações Declaratórias de Constitucionalidade (ADC) 43, 44 e 54 , que foram julgadas procedentes. Para a corrente vencedora, Art. 283 do CPP, está de acordo com o princípio da presunção de inocência, garantia prevista no artigo 5으, inciso LVII, da Constituição Federal.

O Ministro do STF Gilmar Mendes, disse que em 2016 após decisão de aceitar o cumprimento provisório da pena, qual seja, execução da pena antes do trânsito em julgado, os tribunais tomaram com regra e não como uma possibilidade distorcendo da previsão legal e ferindo o princípio da presunção de inocência. Essa mesma corte antes de 2016 entendia que era possível a prisão após condenação em 2 a instância, ora entende uma coisa ora entende outra sobre a mesma matéria, transmite incerteza e que as decisões têm cunho político e pessoal quando se trata de pessoas influentes no cenário político nacional.

Vivemos em uma democracia com a presença de limitadores das ações humanas bem como uma ordem constitucional que nos permite participar através das opiniões, manifestações lícitas, representação por partidos políticos e um governo da maioria com respeito às minorias para que não se torne um autoritarismo.

Neste sentido Carvalho (2013, p. 104) diz:

Um consenso em favor da democracia só é promissor em aparência, porque a democracia, por definição, consiste em prescindir de todo consenso. Democracia não é concórdia: é uma maneira inteligente de administrar a discórdia. E o clamor universal por "mais democracia", na medida mesma em que se afirma como um consenso, já dá sinais de não poder suportar 
nenhuma voz discordante. Assim, há razões para temer que, se o século $X X$ começou pedindo ditaduras e terminou por exigir a democracia, o novo século acabe por seguir o trajeto precisamente inverso. Afinal, dizia Bernanos, a democracia não é o oposto da ditadura: é a causa dela.

Os problemas sociais continuam os mesmos, quer seja pela característica da evolução social, em que o direito tem que evoluir para acompanhar as necessidades da sociedade, mas, em prova disso a expansão judicial não é capaz de resolver esses problemas, pois eles continuam presentes. $O$ que acontece é que o governo não consegue garantir todos os "direitos" previstos para as minorias, a mídia e as instituições de ensino propagam uma falsa ilusão que esses direitos não são respeitados e que por isso essa minoria é posta de lado.

O que acontece no ativismo judicial é uma distorção da lei por uma única pessoa e não pelo plenário. Caso em que o STF pelo seu status supremo como último instância e, não existir outro para regular suas ações ou até mesmo revisar seus atos, realmente o torna supremo diante todos os outros, liberando caminho para o governo agir convenientemente a seus interesses.

Um dos ingredientes do ativismo é a interpretação dentro do controle discricionário do julgador, para o filósofo Rodriguez (2013b, p. 202) enfatiza que "a segurança jurídica tem sido pensada como a existência de respostas únicas e unívocas para os problemas jurídicos apresentados diante do Poder Judiciário".

Continua Rodriguez (2013b, p. 202) que a criatividade do julgador não depende de o texto ser fechado ou aberto:

Há muito tempo a teoria do direito tem mostrado que, mesmo diante de textos fechados, os juízes encontram espaço para criar interpretações com fundamento em justificativas que extrapolam uma interpretação meramente literal dos mesmos.

Por fim, quando se buscar direção para atuar em alinhamento com a Constituição no âmbito judicial, dentro dos preceitos do Estado Democrático de Direito, é preciso na visão Rodriguez, (2013b, p. 203):
Reformular o conceito de segurança jurídica em função da argumentação que fundamenta as decisões judiciais e não em função do texto legal. A possibilidade de se obter mais de uma resposta para as questões jurídicas é um fato normal que deve ser levado em conta na definição da segurança jurídica e não servir como argumento para afirmar sua impossibilidade. [...] talvez seja mais adequado trabalhar com textos normativos abertos e, para buscar restringir as possibilidades interpretativas, criar mecanismos que formalizem de alguma maneira o procedimento destinado a solucionar casos concretos a partir deles.[...]no que se refere à atividade jurisdicional, os tribunais seriam o local adequado para promover este tipo de debate tendo em vista a padronização da interpretação da fundamentação das normas jurídicas.

O que se busca no Judiciário é a garantia da segurança jurídica, o exposto acima nos diz que se o foco estiver fora do texto legal mas também na dimensão argumentativa, o ativismo judicial não será algo lesivo ao Estado Democrático de Direito, princípio da separação de poderes, acaba por perder o sentido. Para tanto há de se combater a ocorrência das zonas de autarquia, em que aí sim será prejudicial ao Estado Democrático de Direito.

Um importante mecanismo é o diálogo, serve como instrumento entre os sujeitos sociais e a sociedade como fator essencial para a concretização da democracia com o seu maior interessado: o povo.

\section{CONCLUSÃO}

De acordo a pesquisa, o ordenamento jurídico adotado foi o sistema tripartite e os órgãos que compõe esse sistema tem as suas funções bem definidas e para um bom funcionamento e eficácia a independência dos poderes entre si.

O judiciário ao adotar uma posição ativista gera insegurança jurídica e coloca em risco a democracia brasileira. A função típica do judiciário em especial o Supremo Tribunal Federal por ser inerte tem que agir com imparcialidade quando provocado no caso concreto, aplicar as normas positivadas sem adotar posições ativistas, criando direitos e deveres ferindo a independência dos poderes gerando desarmonia.

Esta atuação do Judiciário em adentrar a esfera do poder Legislativo e Executivo, cria uma relativização 
sobrepondo às leis legalmente votadas e sancionadas por parte da classe política. Os poderes que foram conferidos pela Constituição Federal de 1988 ao STF têm um status de supremacia, não há no ordenamento jurídico atual nenhum órgão capaz de revisar seus atos bem como os de criar. Essa supremacia é fato, prova disso é uma atuação dos Ministros maior que a vontade popular representada pelo congresso nacional.

Para tanto, o poder constituinte ao separar os poderes e distribuir suas funções deixou clara a importância em se respeitar a autonomia um do outro, zelar pela relação institucional para uma aplicabilidade das normas de forma isonômica e independente, gerando segurança, confiança, respeito recíproco entre os atores sociais.

O Supremo Tribunal Federal ao agir de forma proativa, inverte esse pensamento, o que traz preocupação aos operadores do direito ao preencher as lacunas por falha do sistema Legislativo, e esse não é motivo suficiente para que o Judiciário as resolva atuando de forma contra majoritária sim na autocontenção judicial cumprimento à Constituição Federal de 1988 e as normas infraconstitucionais.

Conclui-se ser um problema emergente com ações prejudiciais por parte de quem é responsável de sustentar o sistema jurídico no campo da eficiência. Isto posto, é dever dos parlamentares legalmente eleitos pelo povo com parcela de contribuição dos operadores do direito, na busca de mecanismos eficientes e capazes de interpretar não no sentido de autoridade, mas com racionalização da decisão como elemento democrático deliberativo entre o povo, instituições e poderes legitimados.

\section{6}

\section{REFERÊNCIAS}

APPIO, E. Direito das minorias. São Paulo; RT,2008.

BARBOSA, O. P. de A.; SARACHO A. B. Considerações sobre a teoria dos freios e contrapesos. RJLB, Ano 5 , no 2. 2019.

BARROSO, L. R. Curso De Direito Constitucional Contemporâneo: os Conceitos Fundamentais e a Construção do Novo Modelo. 7 Ed. São Paulo. Saraiva Educação. 2018.

BARROSO, L. R. Curso de direito constitucional, 3a Ed. São Paulo: Saraiva,Disponível em: https://conteudojuridico.com.br/consulta/Artigos/4 7213/ativismo-judicial-aspectos-historicos-econceituais. Acesso em 15 set. 2019.

BARROSO, L. R. Judicialização, ativismo judicial e legitimidade democrática. Disponível em: https://www.direitofranca.br/direitonovo/FKCEimag ens/file/ArtigoBarroso para Selecao.pdf. Acesso em 15 de set. 2019.

CAMPOS, C. A. de A. Dimensões do Ativismo Judicial do Supremo Tribunal Federal. Rio de Janeiro: Forense, 2014.

CARVALHO, O. O Mínimo que você precisa saber para não ser um idiota. Organização Felipe Moura Brasil. - 5.Ed. - Rio De Janeiro: Record, 2013.

DANTAS, M. N. R. Cidadania e Separação de Poderes; De Montesquieu a atualidade. Disponível em: https://www.editorajc.com.br/cidadania-eseparacao-de-poderes-de-montesquieu-aatualidade/. Acesso em 15 set. 2019.

DIAS, J. A.; OLIVEIRA, E. A. B. de. Jurisdição civil, ativismo e ordem econômica. Rio de Janeiro: Lumes Juris, 2017.

FERRAZ JR., T. S. Argumentação jurídica. São Paulo: Editora Manole, 2014.

FERRAZ JUNIOR, T. S. Introdução ao estudo do direito: técnica, decisão, dominação. 0. ed. rev., atual. e ampl. São Paulo: Atlas, 2018.

KELSEN, H. Teoria geral do direito e do estado, 1998.

KINCHESCKI. C. A supra constitucionalidade dos Tratados Internacionais de Direitos Humanos, 2006. p. 81. Revista da Faculdade Mineira de Direito, v.15, n. 29, jan./jun. 2012.

MONTESQUIEU. Do espírito das leis. Trad. Cristina Murachco. São Paulo: Martins Fontes, 2000.

MORAES, A. de. Direito constitucional. 32. ed. rev. e atual. São Paulo: Atlas, 2016.

OLIVEIRA, A. C. Poderes do Estado - Executivo, Legislativo e Judiciário. Disponível em: https://educacao.uol.com.br/disciplinas/cidadania/p oderes-do-estado-executivo-legislativo-ejudiciario.htm?cmpid=copiaecola. Acesso em 15 set. 2019. 
RODRIGUEZ, J. R. Como decidem as cortes: para

uma crítica do Direito (Brasileiro). Fgv Editora: Rio De Janeiro, 2013b.

RAMOS, E. da S. Ativismo judicial parâmetros

dogmáticos. 2. ed. São Paulo: Saraiva, 2015.

SCALIA, A.; GARNER, B. A. R. L. The Interpretation of Legal Texts. Editora: St. Paul, MN: Thomson/West. 2012.

SCHLESINGER JR., A. M. The Supreme Court: 1947. Fortune, v. 35, n. 73, jan. 1947.

STRECK, L. L. Verdade e consenso: constituição, hermenêutica e teorias discursivas. 4. ed. São Paulo: Saraiva, 2011.

TASSINARI, C. Jurisdição e ativismo judicial: limites da atuação do Judiciário. Porto Alegre: Livraria do Advogado, 2013. 